\title{
Cooling strategies for greenhouses in summer: Control of fogging by pulse width modulation
}

\author{
A. Perdigones , J.L. Garcia , A. Romero , A. Rodriguez , L. Luna , \\ C. Raposo , S. de la Plaza \\ Departamento de Ingenierfa Rural, Uniuersidad Politecnica de Madrid, E.T.S.I. Agronomos, 28040 Madrid, Spain \\ Departamento de Ingenieria Rural, Uniuersidad Politecnica de Madrid, E.U.I.T. Agricola, Ciudad Uniuersitaria s/n, 28040 Madrid, Spain
}

The possibilities for improving the control of greenhouse fogging systems, were studied by comparing several combinations of ventilation cooling techniques, shade screening and low-pressure fogging. The study was divided into three parts: experiments, modelling and simulations.

In the first part of the paper, ten combinations of five cooling techniques were tested during the summers of 2002 and 2003 in a $132 \mathrm{~m}^{2}$ greenhouse with a steel structure and a single-layer methacrylate cover located in Madrid, Spain. An analysis of variance of the climatic parameters was carried out to determine which combinations produced significant differences in inside temperature or relative humidity. Comparing the values for the inside to outside temperature difference, the combination of a shade screen and above-screen fogging achieved a difference in temperature almost the same as that for under-screen fogging, but the relative humidity was significantly lower.

In the second part of the study a dynamic model was developed (2002) and validated (2003). The mean absolute error obtained for inside temperature was similar in the fit and the validation and it was less than $1.5{ }^{\circ} \mathrm{C}$ in both cases.

The model was used to simulate the inside air temperature for a fog system working without shading, and above and under a shade screen. Control algorithms were developed for reducing system water consumption. In the three cases a simple on/off control with a fixed fogging cycle was compared with a pulse width modulation (PWM) strategy, in which the duration of the fogging pulse was increased as a function of inside temperature. The strategies with PWM applied to the fog system were able to reduce water consumption by $8-15 \%$ with respect to the strategies with a fixed fogging cycle.

\section{Introduction}

Air cooling is necessary in many greenhouses based in Mediterranean climates to prevent plant stress and produce market-quality crops (Hanan et al., 1978). There are a number of cooling techniques that can help to efficiently maintain the temperature and humidity of a greenhouse at acceptable levels during hot periods, although they often need reliable models for estimating cooling loads and to properly manage the climate control equipment (Kittas et al., 2003). Natural ventilation, whitening, shade screens and evaporative cooling (i.e. wet padfan and fogging systems) are the most common techniques. 


\author{
Nomenclature \\ b \\ C heat capacity, $\mathrm{J} \mathrm{m} \sim^{2} \mathrm{C}^{-1}$ \\ $\mathrm{F} \quad$ cooling effect of fogging, $\mathrm{Wm} \sim^{2}$ \\ $\mathrm{S}$ solar radiation flux outside the greenhouse, \\ $\mathrm{Wm} \sim^{2}$ \\ $\mathrm{t} \quad$ time, $\mathrm{s}$ \\ T; $\quad$ inside air temperature, ${ }^{\circ} \mathrm{C}$
}

\begin{tabular}{|c|c|}
\hline $\mathrm{T}_{0}$ & outside air temperature, ${ }^{\circ} \mathrm{C}$ \\
\hline$A T$ & temperature difference $\left\{T_{0}-T i\right),{ }^{\circ} \mathrm{C}$ \\
\hline $\mathrm{T}_{\text {sim }}$ & simulated inside air temperature, ${ }^{\circ} \mathrm{C}$ \\
\hline $\mathrm{U}$ & overall heat transfer coefficient, $\mathrm{W} \mathrm{m}^{-20} \mathrm{C}^{-1}$ \\
\hline V & $\begin{array}{l}\text { overall heat transfer coefficient due to ventilation, } \\
\mathrm{w} \mathrm{m}^{\wedge} \mathrm{cr}^{1}\end{array}$ \\
\hline W & fogging rate, $1 \mathrm{~m}^{-2} \mathrm{~h}^{-1}$ \\
\hline $\mathrm{T}$ & cover transmittance \\
\hline
\end{tabular}

$\mathrm{T}_{0} \quad$ outside air temperature, ${ }^{\circ} \mathrm{C}$

temperature difference $\left\{T_{0}-T i\right\},{ }^{\circ} \mathrm{C}$ overall heat transfer coefficient due to ventilation, $\mathrm{w} \mathrm{m}^{\wedge} \mathrm{cr}^{1}$

cover transmittance
Natural ventilation is considered one of the most important factors of greenhouse environment, since it directly affects transport of sensible, latent heat and $\mathrm{CO}_{2}$ to or from the interior air. Under high radiative loads efficient acclimatisation is crucial to decrease the inside air temperature and to remove excess humidity (Boulard \& Bailie, 1993).

High ventilation rates are not a priori the best solution for reducing water stress in greenhouses under summer conditions. Ventilation reduces greenhouse overheating but increases the risk of water stress, as it often increases plant transpiration (Seginer, 1984). Greenhouses with ventilation often reach high temperatures when there are high levels of solar radiation. With shade screens, the real temperature reduction is not proportional to the shading rate (Kittas et al., 2001).

If temperatures inside a greenhouse in summer are to be kept below outside temperatures, the greenhouse requires some sort of a evaporative system. These systems are based on converting sensible heat into latent heat through the evaporation of water, which is supplied mechanically. A suitable combination for supplying a flow of air through the greenhouse and water to be evaporated, in line with environmental conditions (solar radiation, temperature and relative humidity of the outside air), is an essential requirement for maintaining the required conditions in the greenhouse (Arbel et al., 1999). These evaporative systems substantially improve the greenhouse climate (Carpenter \& Willis, 1957); temperature is reduced and absolute humidity is increased in the greenhouse, which helps to lower the vapour pressure deficit and moderate the demand for transpiration (Katsoulas et al., 2001). Fogging is one of the systems that can be used for direct evaporative cooling in greenhouses. Highpressure fogging systems have recently started to be used. They are based on fogging water into droplets with diameters in the range of 2-60 ^im as a means of increasing the water surface area in contact with the air (Arbel et al., 2000). Water is forced out through nozzles located above the crop, producing a fog. The fall speed of the droplets is low, and they are easily transported by the airflow within the greenhouse. High-pressure fogging has been found to maintain more uniform temperature and humidity levels than evaporative pad systems although generally fog systems are relatively less efficient than evaporative pad systems (Luchow \& von Zabeltitz, 1992). High-pressure fogging systems are more expensive, but generally appear to be the best method when temperature and humidity levels need to be kept constant (Oztiirk \& Bascetincelik, 2002).
Earlier work on greenhouse cooling, primarily by means of fogging, has evaluated the efficiency of the thermodynamic system and the ambient effects (Oztiirk, 2003). Giacomelli et al. (1985), Montero et al. (1990) and Arbel et al. (1999) studied the effects of fog cooling on the greenhouse microclimate. They demonstrated the benefits of using a fog cooling system to achieve more uniform temperature and humidity conditions by controlling air flow rate and fogging rate as a function of solar radiation and other climate factors. This did not produce the horizontal gradients produced by evaporative pads. This encouraged further research into combining fogging with natural ventilation and other systems. Other studies analysed a range of variables in a combination of fogging and forced ventilation with fans on both sides of the greenhouse (e.g. Arbel et al., 2003).

One of the problems in greenhouses is controlling condensation on the crop and the cover. This causes losses of radiation and dripping on the crop, encouraging the proliferation of cryptogamic diseases. There is no condensation on the cover under hot summer, daytime conditions. There are a number of studies addressing condensation control strategies (Perales et al., 2003).

The objective of this study was to quantify the relationship between a number of different fogging rates and cooling with the aim of being able to regulate water consumption. Another aim was to determine whether cooling is more efficient when fogging was carried out underneath or above the shade screen in a combination of fogging and a shade screen. Arbel et al. (1999) recommended a method of controlling the fog system as a function of cooling needs. To facilitate this, a model that estimates the inside greenhouse temperature was developed, and was used in simulations to study and compare the behaviour of fogging with on/off control and with pulse width modulation (PWM) control as a function of the temperature in the greenhouse at any time. The PWM technique controlled the fog system as a function of cooling needs.

\section{Materials and methods}

\subsection{Greenhouse and experimental arrangement}

The experimental greenhouse had a straight sidewall and an arched roof structure with a galvanised steel frame and a rigid plastic (methacrylate) cover and was located in Madrid, Spain. The ground area was $132 \mathrm{~m}^{2}: 6.6 \mathrm{~m} \times 20 \mathrm{~m}$ (Fig. 1). The greenhouse shared a sidewall with an adjacent greenhouse, although this wall was also covered with methacrylate. The 

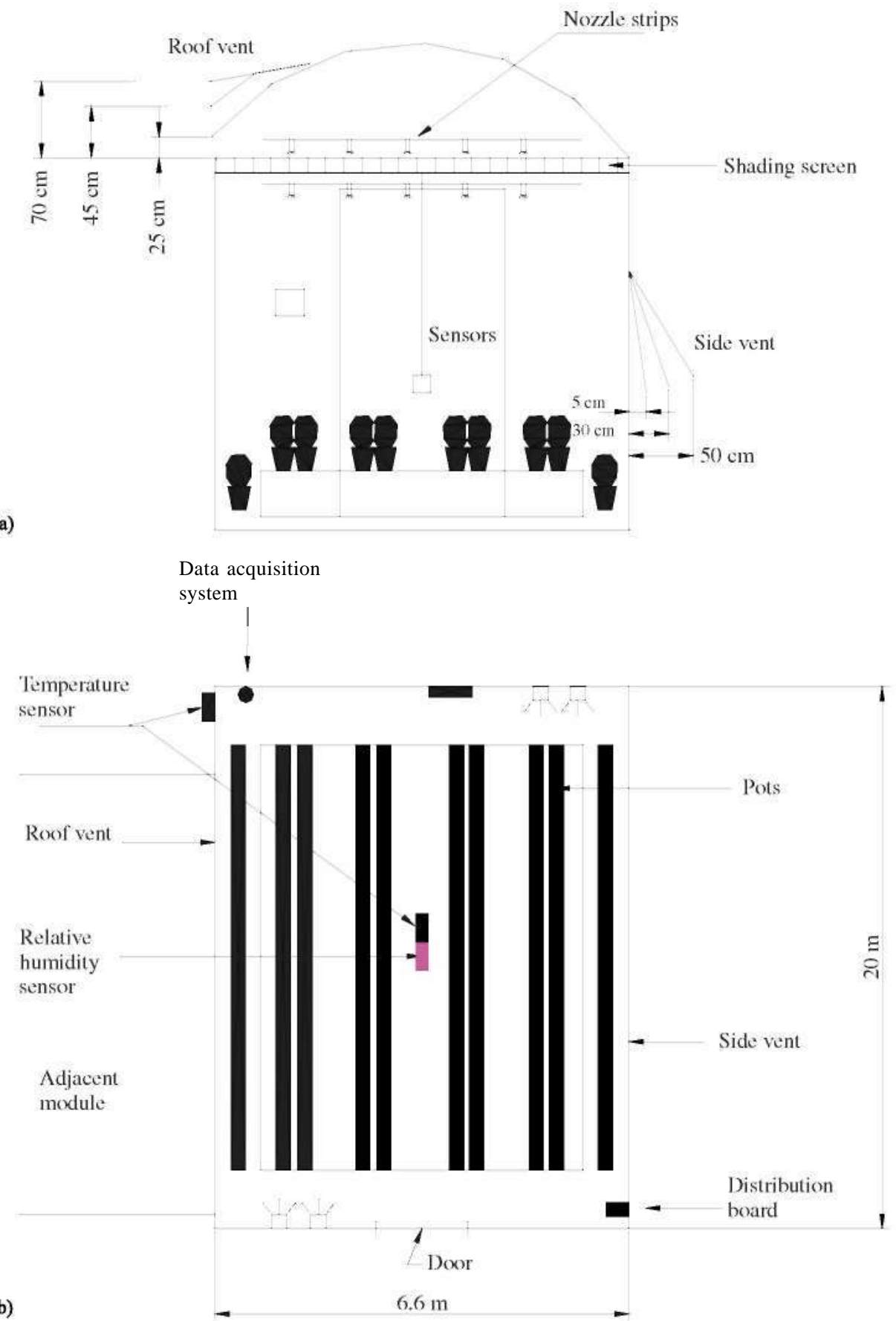

Fig. 1 - (a) Top view; (b) side view of the experimental greenhouse layout.

height to the gutter was $3 \mathrm{~m}$ and the area covered with methacrylate and exposed to outside air was $258 \mathrm{~m}^{2}$.

In 2002, Gerbera jamesonii (African daisy) was cultivated in pots inside the greenhouse; $25 \%$ of the ground was covered by the pots. The crop height was less than $0.5 \mathrm{~m}$, and the crop density was 4 plants $m r^{2}$. In 2003, Helianthus annuus L. (sunflower) was grown in the same pots inside the greenhouse, with a crop density of 2 plants $m r^{2}$.

With respect to ventilation, the greenhouse had a ridge roof vent running the length of the greenhouse that could open half of the roof. The side vent extended from the gutter down to a height of $2 \mathrm{~m}$ above ground and also ran the length of the greenhouse; it was located on the opposite side of the greenhouse to the roof vent.

The shade screen, measuring $6.6 \mathrm{~m}$ x $20 \mathrm{~m}$ (five $4 \mathrm{~m}$ strips), was placed at gutter height $(3 \mathrm{~m})$; it was an aluminised net with nominal values of $75 \%$ shade and $60 \%$ energy saving. A three-phase motor operated the traction mechanism for shade extension and retraction. Although the shade screen could be opened and folded automatically, it was used in the experiments as if it were fixed on the days when it was scheduled for use. 
The fogging nozzles were positioned above and below the shade screen (Fig. 1), so that their effect in either position could be compared. The equipment located above the screen was composed of 22 low-pressure nozzles, and the equipment below the screen was composed of 25 of the same nozzles. The fogging system included; a water tank, a water pump, controllers, valves, nozzles and a piping system.

The nozzles were operated discontinuously in cycles, for example, $12 \mathrm{~s}$ every $4 \mathrm{~min}$ or $8 \mathrm{~s}$ every $1 \mathrm{~min}$, depending on the strategy in use during the hottest hours of the day (i.e. from 13:00 to $18: 00 \mathrm{~h}$ ).

Two data acquisition systems were used (Datataker DT50) to store the climatic parameters inside and outside the greenhouse. The air temperature was measured at the centre of the greenhouse by a PT100 sensor positioned $1.5 \mathrm{~m}$ from the ground, and relative humidity with an E+E Elektronik capacitive sensor (4-20 mA per $0-100 \%$ relative humidity) positioned at a height of $0.5 \mathrm{~m}$. With respect to the outside climate parameters, global radiation was measured with a Skye Instruments pyranometer $\left(4.778+\mathrm{A}\right.$ per $\left.100 \mathrm{Wm}^{2}\right)$ and outside temperature with a PT100 sensor positioned $1.5 \mathrm{~m}$ from the base, and relative humidity with a sensor identical to the meter installed inside the greenhouse, positioned on the ridge, $4.5 \mathrm{~m}$ above the ground level. The temperature sensors (four-wire PT100) were placed inside polystyrene cages to prevent possible interferences in the reading because of the direct incidence of solar radiation.

The above-mentioned parameters were logged every $5 \mathrm{~min}$. The mean daily values for the temperature gap (i.e. the difference between the inside and outside temperature, $\mathrm{T} ;-\mathrm{T}_{0}$ ), the inside temperature and the inside relative humidity were calculated between 14:00h and 17:00h.

\subsection{Experimental cooling strategies}

The experiments were carried out during the 2002 and 2003 summer seasons. The collected data covered 118 days in 2002 and 97 days in 2003 with nine combinations tested in 2002 (numbered from 1 to 9) and six combinations tested in 2003 (denoted 1-4, 6 and 10), five of which were common to both 2002 and 2003.

Consequently, all the following ten combinations of cooling techniques, including natural ventilation, shade screen and low-pressure fog system, were used:

(1) side and roof ventilation;

(2) side and roof ventilation and a shade screen;

(3) side and roof ventilation and fogging, without a shade screen (12 s every $\left.4 \mathrm{~min} ; 0.61 \mathrm{~m} \sim^{2} \mathrm{~h}^{-1}\right)$

(4) side and roof ventilation, shade screen and fogging under the screen ( $8 \mathrm{~s}$ every $\left.1 \mathrm{~min} ; 1.31 \mathrm{~m}^{2} \mathrm{~h}^{-1}\right)$;

(5) side and roof ventilation, shade screen and fogging under the screen ( $8 \mathrm{~s}$ every $4 \mathrm{~min} ; 0.3251 \mathrm{rrr}^{2} \mathrm{~h}^{-1}$ );

(6) side and roof ventilation, shade screen and fogging above the screen ( $8 \mathrm{~s}$ every $1 \mathrm{~min} ; 1.61 \mathrm{~m} \sim^{2} \mathrm{~h}^{-1}$ );

(7) side and roof ventilation, shade screen and fogging above the screen (12 s every $4 \mathrm{~min} ; 0.61 \mathrm{rrr}^{2} \mathrm{~h}^{-1}$ );

(8) side and roof ventilation, shade screen and fogging above the screen ( $8 \mathrm{~s}$ every $\left.4 \mathrm{~min} ; 0.41 \mathrm{~m} \sim^{2} \mathrm{~h}^{-1}\right)$;
Table 1 - Distribution of the days belonging to each cooling strategy

\begin{tabular}{lcc}
\hline $\begin{array}{l}\text { Average day } \\
\text { (Cooling strategy) }\end{array}$ & \multicolumn{2}{c}{ Experiment days } \\
\cline { 2 - 3 } & Year & Year \\
& 2002 & 2003 \\
\hline 1 & 21 & 19 \\
2 & 14 & 19 \\
3 & 13 & 15 \\
4 & 11 & 15 \\
5 & 13 & - \\
6 & 12 & 14 \\
7 & 9 & - \\
8 & 13 & - \\
9 & 12 & - \\
10 & - & 15 \\
Total (days) & 118 & 97 \\
\hline
\end{tabular}

(9) side and roof ventilation, shade screen and fogging above the screen ( $12 \mathrm{~s}$ every $\left.8 \mathrm{~min} ; 0.31 \mathrm{rrr}^{2} \mathrm{~h}^{-1}\right)$;

(10) side and roof ventilation and fogging, without shade screen ( $8 \mathrm{~s}$ every $1 \mathrm{~min} ; 1.61 \mathrm{~m}^{2} \mathrm{~h}^{-1}$ ). This case was only tested in the year 2003 .

Each combination was switched every 1 or 2 days throughout the trial period to offset any differences between early and late summer. Table 1 gives an overview of the days belonging to each combination.

Analyses of variance were conducted primarily to analyse the inside temperature, temperature gap and the inside relative humidity.

The STATGRAPHICS program was used to run the following analyses of variance:

(a) For the year 2002, cases 6-9 were compared to try to determine what influence the fogging rates and times had. Nine days per tested combination were used to do this.

(b) Cases 1-4 and 6 for 2002 and 1-4, 6 and 10 for 2003 were compared to determine what cooling techniques were most effective for reducing the inside temperature. Eleven days were used for each strategy in 2002 and 14 days for each strategy in 2003.

\subsection{Energy balance model}

An energy balance model was developed based on the energy conservation equation to evaluate the energy fluxes involved. Similar in situ calibration models have been used in the past (Albright et al., 1985; Perdigones et al., 2005, 2006). The energy fluxes considered were as follows:

(1) Energy supplied by solar radiation: The energy supplied in $\mathrm{Wm} \sim^{2}$ by solar radiation is given by ibS where $\mathrm{T}$ is the transmittance of the greenhouse cover, $b$ is the percentage of solar radiation converted into sensible heat and $\mathrm{S}$ is 
the solar radiation flux outside the greenhouse in $\mathrm{W} \mathrm{m}^{2}$. Two values for $\mathrm{ib}$, with and without a shade screen, were used.

(2) Structure-induced energy losses: Structure-induced energy losses in $\mathrm{Wm} \sim^{2}$ are given by $\mathrm{U}\left(\mathrm{T} ;-\mathrm{T}_{0}\right)$ where $\mathrm{U}$ is the overall heat transfer coefficient (with closed vents). Two $\mathrm{U}$ coefficients were used, $11.8 \mathrm{Wm}^{-20} \mathrm{C}^{-1}$ with aluminised shade screen and $14.8 \mathrm{Wm}^{-20} \mathrm{C}^{-1}$ without a shade screen. These values for $U$ were determined throughout the preceding winter following the same methodology as described in Section 2.4; they are easier to determine in winter with a heating supply.

(3) Energy losses through open uents: Energy losses in $\mathrm{Wm} \sim^{2}$ through open vents are given by $\mathrm{V}\left(T i-T_{0}\right)$ where $\mathrm{V}$ is the overall heat transfer coefficient in $\mathrm{Wm}^{-20} \mathrm{C}^{-1}$ (through open vents). Again there were two values for coefficients V: with and without a shade screen.

(4) Heat conuersion: The sensible heat was converted into latent heat of vaporisation of water by the fog system, $F$ in $\mathrm{Wm}^{2}{ }^{2}$.

(5) Greenhouse heat accumulation: Greenhouse heat accumulation in $\mathrm{Wm} \sim^{2}$ is given by $\mathrm{C}(\mathrm{dT} / \mathrm{dt})$, where $\mathrm{C}$ is the capacity heat of the greenhouse as a thermal mass in $\mathrm{Jm}^{-20} \mathrm{C}^{-1}$ and $t$ is the time in $s$.

As the energy balance was dynamic, the sum of the energy fluxes, is different from zero in each period. The excess energy is stored or released by the thermal mass, affecting the value of the inside air temperature in the following period. The inside temperature for each period could be calculated from the parameters of the last period according to the following equation:

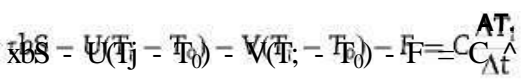

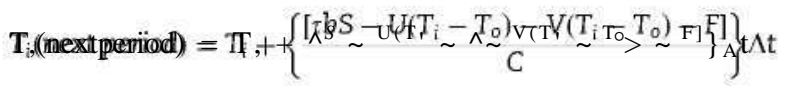

\subsection{Model calibration and extraction of coefficients}

The model coefficients (ib, V, F and C) were calculated using the experimental data recorded in the year 2002 (118 days).

The models were to the data fitted by iteration using Microsoft Excel ${ }^{\circledR}$ until there was a minimum mean absolute difference between the real and simulated inside air temperature. The outside temperature and solar radiation measured in each period, the ventilation, shade screen and fogging operation and the original inside temperature were used as processing inputs; the ib, V, F and $\mathrm{C}$ coefficients were the outputs. All the input data were logged every $5 \mathrm{~min}$. The inside air temperatures were calculated in each iteration with a constant value of the above coefficients from the values of the last 5-min period. The overall absolute error of the iteration was logged and then a new iteration was started with other coefficient values until the error could be reduced no further. Microsoft Excel@ SOLVER was used to run the search procedure. This add-in software allows some variables to be altered for the purpose of minimising any given error. Therefore, the software tool searched the best $\mathrm{ib}, \mathrm{V}, \mathrm{F}$ and $\mathrm{C}$ coefficients, assuring that the simulated inside temperature was as close as possible to the real temperature.

The model gives the energy values in $\mathrm{Wm} \sim^{2}$ of each energy flux for each of the 10 cooling combinations techniques.

These values were used to relate water consumption to the cooling effect of fogging $\mathrm{F}$ in $\mathrm{Wm} \sim^{2}$ provided by each fogging type and rate. Both parameters were fitted by linear regression for the cases in which there was no shade screen and cases where fogging was done under this screen. For cases where fogging was done above the shade screen, logarithmic regression was applied as there were four different rates.

\subsection{Model validation}

The model was validated against the data gathered in 2003 . Data were logged on 97 days in 2003, but the model was only validated for the 82 days corresponding to cooling strategies 1-4 and 6. The model was applied using the coefficients extracted for 2002 on the data of 2003 to check whether the inside temperature estimated by the model was close to the measured temperature.

\subsection{Simulation}

Two strategies were simulated and evaluated using the model during the summer period (from June to August) in Madrid, where the outside temperature and radiation were measured at 10 -min intervals throughout the above 3 months of an average year.

The ventilation, screen and fogging conditions were regulated in the simulations by means of thermostats as follows:

(1) ventilation with opening/closing settings of $26 / 24^{\circ} \mathrm{C}$

(2) screen with folding/opening settings of $26 / 28{ }^{\circ} \mathrm{C}$; and

(3) fogging with setting of $28^{\circ} \mathrm{C}$.

\subsubsection{Reference simulation tuith on/off fogging control}

The resulting inside climate was compared in the cases without a shade screen, with a shade screen and fogging above, and with a shade screen with fogging underneath using different fogging rates. In this way, it was aimed to determine what changes there are in the inside temperature when these factors are varied. From the simulations it was possible to determine the total water consumption in summer in each case. This strategy is shown in Fig. 2; fogging is activated at the temperature setting and is maintained throughout a fixed cycle.

The mean temperature in ${ }^{\circ} \mathrm{C}$, mean maximum temperature in ${ }^{\circ} \mathrm{C}$ and mean water consumption in $1 \mathrm{~m}^{-2} \mathrm{day}^{-1}$ were calculated in the three cases (i.e. without a screen, with a screen fogging under, and with a screen fogging above) for fogging rates of $0.5,1$ and $1.51 \mathrm{~m} \sim{ }^{2} \mathrm{~h}^{-1}$. The cooling effect of fogging at these rates, was taken into account and calculated using the formulae obtained by regression fitting [Eqs. (2)-(4)]. 


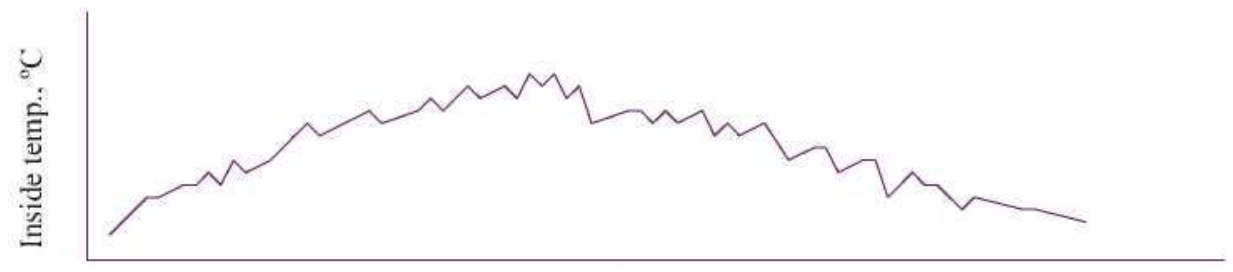

Time

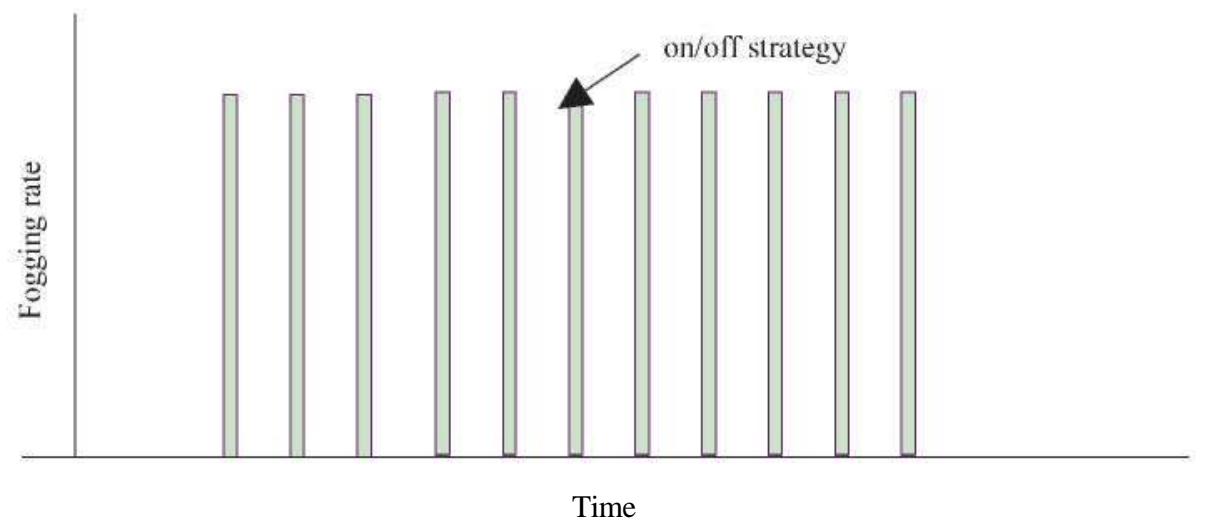

Fig. 2 - On/off control strategy with a fixed fogging cycle.

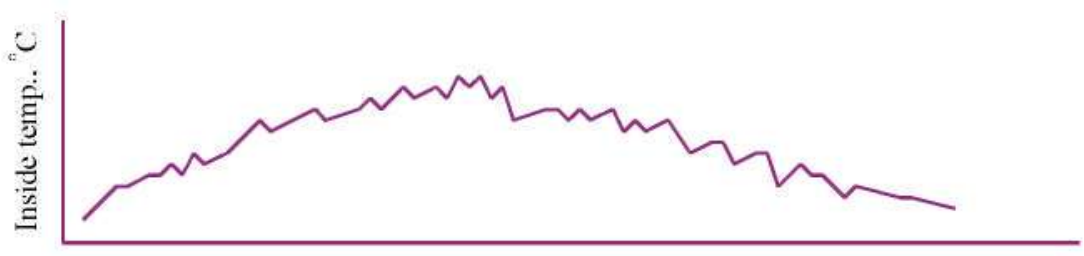

Time

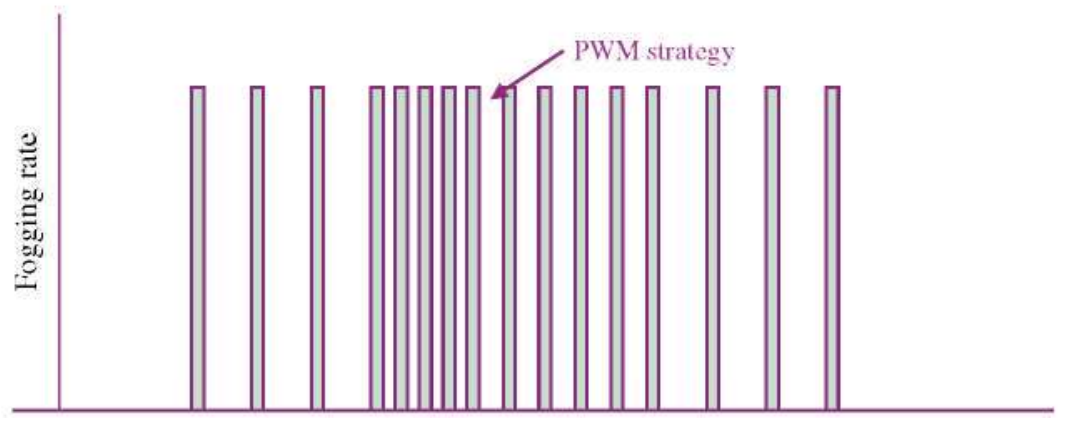

Time

Fig. 3 - Pulse width modulation (PWM) control strategy; fogging frequency depends on the error in ${ }^{\circ} \mathrm{C}$, with respect to the $28{ }^{\circ} \mathrm{C}$ temperature setting.

\subsubsection{Simulation tuith pulse width modulation Jogging} control

For PWM control, the error between the simulated temperature and the temperature setting $\left(28^{\circ} \mathrm{C}\right)$ was calculated. Only positive errors were taken into account. When the simulated temperature was below $28^{\circ} \mathrm{C}$, the error was equated to zero, as fogging was regulated to actuate at above $28^{\circ} \mathrm{C}$. The Microsoft Excel ${ }^{\circledR}$ SOLVER tool was used to determine the ratio between the error and the fogging rate that minimised water consumption (with a temperature limit). Having established this ratio, the error was used to determine the fogging rate, whereas the rate was used to obtain the cooling effect of fogging using the regression fits [Eqs. (2)-(4)].

According to this system, the rate in each 10 -min period was determined as a function of the error. The cycles for each rate would vary, lengthening or shortening the fogging pulses depending on the fit from Section 2.4. The maximum and minimum rates applied were 0.5 and $1.51 \mathrm{~m}^{-2} \mathrm{~h}^{-1}$ to keep to the range of the rates used in the reference strategy. This is the PWM-type control strategy (Fig. 3). 
The mean temperature, the mean maximum temperature and mean consumption were calculated for all three cases, without a screen, with a screen (fogging underneath) and with a screen (fogging above).

\section{Results}

\subsection{Experimental results}

The results of the analysis of variance for the year 2002 with cooling strategies 6-9 are shown in Table 2.

As regards the inside temperature and inside relative humidity, there were no significant differences between the four cases examined. There were differences in the temperature gap that are significant at the level of 5\%. Naturally, the greater the fogging frequency, the lower the temperature gap obtained. The strategy that provided the smallest temperature gap in this group was fogging above the shade screen with $8 \mathrm{~s}$ cycles every minute. It is worth mentioning that no significant differences were found between the strategy of $12 \mathrm{~s}$ every $4 \mathrm{~min}$ and $8 \mathrm{~s}$ every $4 \mathrm{~min}$; this result suggests that it is better to increase the cycle frequency than the fogging time in each cycle to increment flux. Studies varying the fogging rate have been conducted in the past (Arbel et al., 2003): the wet bulb temperature did not change significantly with an increase of the fogging rate, as this temperature mainly depends on the heat supply and the ventilation air supply.
However, the fogging flux was supplied in accordance either with the target dry bulb air temperature or as a function of absolute air humidity.

The results of the analysis of variance conducted for the year 2002 for cooling strategies $1-A$ and 6 and for the year 2003 and strategies $1-i, 6$ and 10 are shown in Tables 3 and 4 , respectively.

\subsubsection{Year 2002}

- Inside temperature: The inside temperature turned out to be a less consistent parameter than the temperature gap (as this depends on the outside temperature). Therefore, the analysis focused on the values of the temperature difference.

- Temperature difference: The analysis of variance revealed significant differences between the different strategies, fogging with $8 \mathrm{~s}$ cycles every $1 \mathrm{~min}$ being the strategy that achieved a lower temperature difference. Of these two cooling combinations, the option that yielded the smallest temperature difference was fogging under the shade screen $\left(\mathrm{AT}=-0.18^{\circ} \mathrm{C}\right)$. The strategy with just side and roof ventilation produced a greater temperature difference $\left(\mathrm{AT}=4.39^{\circ} \mathrm{C}\right)$. These results matched the year 2003 results.

- Relatiue humidity: The analysis of variance revealed significant differences between the different strategies. As with temperature difference, the combinations that

Table 2 - Analysis of variance for cooling strategies 6-9; year 2002 (side and roof ventilation in all cases and on/off control)

\begin{tabular}{|c|c|c|c|c|c|}
\hline $\begin{array}{l}\text { Cooling } \\
\text { strategies }\end{array}$ & $\begin{array}{l}\text { Fogging rate } \\
\operatorname{smin}^{-1}\end{array}$ & $\begin{array}{l}\text { Water flow, } \\
1 \mathrm{~m}^{\wedge} \mathrm{h}-{ }^{1}\end{array}$ & $\begin{array}{l}\text { Mean inside temp., } \\
{ }^{\circ} \mathrm{C}\end{array}$ & $\underset{{ }^{\circ} \mathrm{C}}{\text { Temperature gap, }}$ & $\begin{array}{c}\text { Relative } \\
\text { Humidity, \% }\end{array}$ \\
\hline $\begin{array}{l}\text { 6)+shade screen } \\
+ \text { fogging above }\end{array}$ & 8 & 1.6 & $33.02^{\mathrm{a}}$ & $0.84^{\mathrm{a}}$ & $44.32^{\mathrm{a}}$ \\
\hline $\begin{array}{l}\text { 7)+shade screen } \\
+ \text { fogging above }\end{array}$ & 3 & 0.6 & $34.68^{\mathrm{a}}$ & $1.58^{\mathrm{ab}}$ & $3449 a$ \\
\hline $\begin{array}{l}\text { 8)+shade screen } \\
\text { +fogging above }\end{array}$ & 2 & 0.4 & $32.25^{\mathrm{a}}$ & $154 \mathrm{ab}$ & $44.19^{\mathrm{a}}$ \\
\hline $\begin{array}{l}\text { 9)+shade screen } \\
\text { +fogging above }\end{array}$ & 1.5 & 0.3 & $34.8^{\mathrm{a}}$ & $2.67^{\mathrm{b}}$ & $33.30^{\mathrm{a}}$ \\
\hline
\end{tabular}

$a$ and $\mathrm{b}$ indicate to homogeneous groups in the analysis of variance.

Table 3 - Analysis of variance for cooling strategies 1-4 and 6; year 2002; on/off control

\begin{tabular}{|c|c|c|c|c|c|}
\hline Cooling strategies & $\begin{array}{l}\text { Fogging rate, } \\
\operatorname{smin}^{-1}\end{array}$ & $\begin{array}{l}\text { Water flow, } \\
1 \mathrm{~m}^{\wedge} \mathrm{h}-^{1}\end{array}$ & $\begin{array}{l}\text { Mean inside } \\
\text { temp., }{ }^{\circ} \mathrm{C}\end{array}$ & $\begin{array}{c}\text { Temperature } \\
\text { gap, }{ }^{\circ} \mathrm{C}\end{array}$ & $\begin{array}{c}\text { Relative } \\
\text { humidity, \% }\end{array}$ \\
\hline 1) roof and side ventilation & & & $32.25^{\mathrm{ab}}$ & $4.39^{\mathrm{c}}$ & $28.92^{\mathrm{a}}$ \\
\hline 2) $1+$ shade screen & & & $31.57^{\mathrm{a}}$ & $2.94^{\mathrm{b}}$ & $32.40^{\mathrm{ab}}$ \\
\hline 3) $1+$ fogging & 3 & 0.6 & $35.47^{\mathrm{b}}$ & $2.63^{\mathrm{b}}$ & $36.55^{\mathrm{ab}}$ \\
\hline $\begin{array}{l}\text { 4) } 1+\text { shade screen+fogging } \\
\text { under }\end{array}$ & 8 & 1.3 & $32.98^{\mathrm{ab}}$ & $-0.18^{\mathrm{a}}$ & $61.14^{\mathrm{c}}$ \\
\hline $\begin{array}{l}\text { 6) } 1+\text { shade } \\
\text { screen+fogging above }\end{array}$ & 8 & 1.6 & $32.83^{\mathrm{ab}}$ & $0.93^{\mathrm{a}}$ & $44.27^{\mathrm{b}}$ \\
\hline
\end{tabular}

$a, b$ and $\mathrm{c}$ indicate to homogeneous groups in the analysis of variance. 
Table 4 - Analysis of variance for cooling strategies 1-4, 6 and 10; year 2003; on/off control

\begin{tabular}{|c|c|c|c|c|c|}
\hline Cooling strategies & $\begin{array}{l}\text { Fogging rate, } \\
\qquad \operatorname{smin}^{-1}\end{array}$ & $\begin{array}{l}\text { Water flow, } \\
1 \mathrm{~m}^{\wedge} \mathrm{h}-^{1}\end{array}$ & $\begin{array}{l}\text { Mean inside } \\
\text { temp., }{ }^{\circ} \mathrm{C}\end{array}$ & $\begin{array}{c}\text { Temperature } \\
\text { gap, },{ }^{\circ} \mathrm{C}\end{array}$ & $\begin{array}{c}\text { Relative } \\
\text { humidity, \% }\end{array}$ \\
\hline 1) roof and side ventilation & & & $38.14^{\mathrm{b}}$ & $3.84^{\mathrm{c}}$ & $18.63^{\mathrm{a}}$ \\
\hline 2) $1+$ shade screen & & & $34.88^{\mathrm{b}}$ & $2.24^{\mathrm{b}}$ & $27.02^{\mathrm{ab}}$ \\
\hline 3) $1+$ fogging & 3 & 0.6 & $35.30^{\mathrm{b}}$ & $1.46^{\mathrm{b}}$ & $39.79^{\mathrm{bc}}$ \\
\hline $\begin{array}{l}\text { 4) } 1+\text { shade screen+fogging } \\
\text { under }\end{array}$ & 8 & 1.3 & $32.60^{\mathrm{ab}}$ & $-0.73^{\mathrm{a}}$ & $71.80^{\mathrm{d}}$ \\
\hline $\begin{array}{l}\text { 6) } 1+\text { shade } \\
\text { screen+fogging above }\end{array}$ & 8 & 1.6 & $33.51^{\mathrm{ab}}$ & $-0.12^{\mathrm{a}}$ & $41.49^{\mathrm{c}}$ \\
\hline 10) $1+$ fogging & 8 & 1.6 & $31.91^{\mathrm{c}}$ & $-0.90^{\mathrm{a}}$ & $58.59^{\mathrm{d}}$ \\
\hline
\end{tabular}

$a, b, \mathrm{c}$ and $\mathrm{d}$ indicate to homogeneous groups in the analysis of variance.

produced a greater relative humidity were the combinations of fogging with a shade screen ( $8 \mathrm{~s}$ every $1 \mathrm{~min})$, and again fogging under the screen generated greater humidity $(61.14 \%)$ as compared with fogging above the screen $(44.27 \%)$.

\subsubsection{Year 2003}

- Temperature difference: The analysis of variance revealed significant differences between the different strategies, the strategies that yielded a smaller temperature gap being fogging with $8 \mathrm{~s}$ cycles every $1 \mathrm{~min}$. Within the two fogging with a shade screen combinations, the one that achieved the smallest temperature difference was fogging under the shade screen $\left(\mathrm{AT}=-0.73^{\circ} \mathrm{C}\right)$ as compared with fogging above the shade screen $\left(\mathrm{AT}=0.12^{\circ} \mathrm{C}\right.$ ). The temperature difference obtained with fogging without a shade screen was $\mathrm{AT}=-0.90^{\circ} \mathrm{C}$. The strategy with side and roof ventilation only is the one that produced the highest temperature difference $\left(\mathrm{AT}=3.84^{\circ} \mathrm{C}\right)$.

- Relatiue humidity: The analysis of variance revealed significant differences between the different strategies, consistent with those of the year 2002. As for the above variable, the combinations that produced a greater relative humidity were the strategies with a fogging rate $8 \mathrm{~s} \mathrm{~min}^{-1}$, and again fogging underneath the shade screen led to higher relative humidity values $(71.80 \%)$ than fogging above the shade screen $(41.49 \%)$. Fogging without a shade screen $\left(8 \mathrm{~s} \mathrm{~min}^{-1}\right)$ yielded humidity values in between the last two parameters $(58.59 \%)$.

The results highlight the combination of ventilation with a shade screen and fogging above the screen, which manages to achieve near-optimum temperature reductions but does not produce high humidity levels around the plant. This is an interesting combination for crops that require low relative humidity values.

\subsection{Model fitting}

The results with the coefficients taken from the model are shown in Table 5 and Fig. 4. The coefficients were obtained from the 2002 data, except for the cooling effect of fogging $\mathrm{F}$
Table 5 - Coefficients extracted from the model; data for 2002 (except for combination 10, for the year 2003)

\begin{tabular}{lc}
\hline Coefficient & 2002 \\
\hline$x b$ (without screen) & 0.63 \\
$z b$ (with screen) & 0.35 \\
$\mathrm{~V}$ (with screen), $\mathrm{W} \mathrm{m}^{-1}{ }^{-1} \mathrm{C}^{-1}$ & 70.42 \\
$\mathrm{~V}$ (without screen), $\mathrm{W} \mathrm{m}^{-1} \mathrm{C}^{-1}$ & 86.19 \\
$\mathrm{C} \mathrm{J} \mathrm{m- \wedge} \mathrm{C}^{1}$ & 75860 \\
$\mathrm{~F}$ (case 3), $\mathrm{W} \mathrm{m}^{-2}$ & 211.31 \\
$\mathrm{~F}$ (case 4), $\mathrm{W} \mathrm{m}^{2}$ & 273.39 \\
$\mathrm{~F}$ (case 5), $\mathrm{W} \mathrm{m}^{-2}$ & 80.74 \\
$\mathrm{~F}$ (case 6), $\mathrm{W} \mathrm{m}^{-2}$ & 157.39 \\
$\mathrm{~F}$ (case 7), $\mathrm{W} \mathrm{m}^{-2}$ & 118.91 \\
$\mathrm{~F}$ (case 8), $\mathrm{W} \mathrm{m}^{-2}$ & 73.17 \\
$\mathrm{~F}$ (case 9), $\mathrm{W} \mathrm{m}^{-2}$ & 56.66 \\
$\mathrm{~F}$ (case 10), $\mathrm{W} \mathrm{m}^{-2}$ & 601.98 \\
\hline
\end{tabular}

$T$, Cover transmittance; $b$, solar radiation converted into sensible heat; $\mathrm{V}$, overall heat transfer coefficient due to ventilation; $\mathrm{C}$, heat capacity; F, cooling effect of fogging.

for case 10, which was only examined in 2003. As Table 5 shows, the ranges for the values of the cooling effect of fogging, F, are as follows: fogging without a shade screen yields cooling effects of fogging from $211.3 \mathrm{~W} \mathrm{~m}^{-2}$ $\left(0.61 \mathrm{~m}^{-2} \mathrm{~h}^{-1}\right)$ to $602.0 \mathrm{Wm}^{-2}\left(1.61 \mathrm{~m}^{-2} \mathrm{~h}^{-1}\right)$. With belowscreen fogging strategies, cooling effects from $80.7 \mathrm{Wm}^{-2}$ $\left(0.3251 \mathrm{~m}^{\wedge} \mathrm{rr}^{1}\right)$ to $273.4 \mathrm{Wm} \sim^{2}\left(1.31 \mathrm{~m}^{-2} \mathrm{~h}^{-1}\right)$ were obtained. With fogging above the screen, cooling effect values from $56.7 \mathrm{Wm} \sim^{2}\left(\mathrm{O} . \mathrm{S} \mathrm{m}^{\prime 2} \wedge^{1}\right)$ to $157.4 \mathrm{Wm} \sim^{2}\left(1 . \mathrm{elm} \mathrm{m}^{\wedge} \mathrm{rr}^{1}\right)$ were obtained.

It might not seem correct to assign a constant cooling effect of fogging to each fogging rate, bearing in mind that the process depends on the level of solar radiation, temperature and vapour pressure deficit. However, it should noted that in this study fogging will only be applied with high solar radiation (greater than $700 \mathrm{Wm} \sim^{2}$ ), high temperatures (above $28^{\circ} \mathrm{C}$ ) and also high vapour pressure deficit. Under such restrictive conditions, typical of Mediterranean summers, it was considered that it is reasonable to 


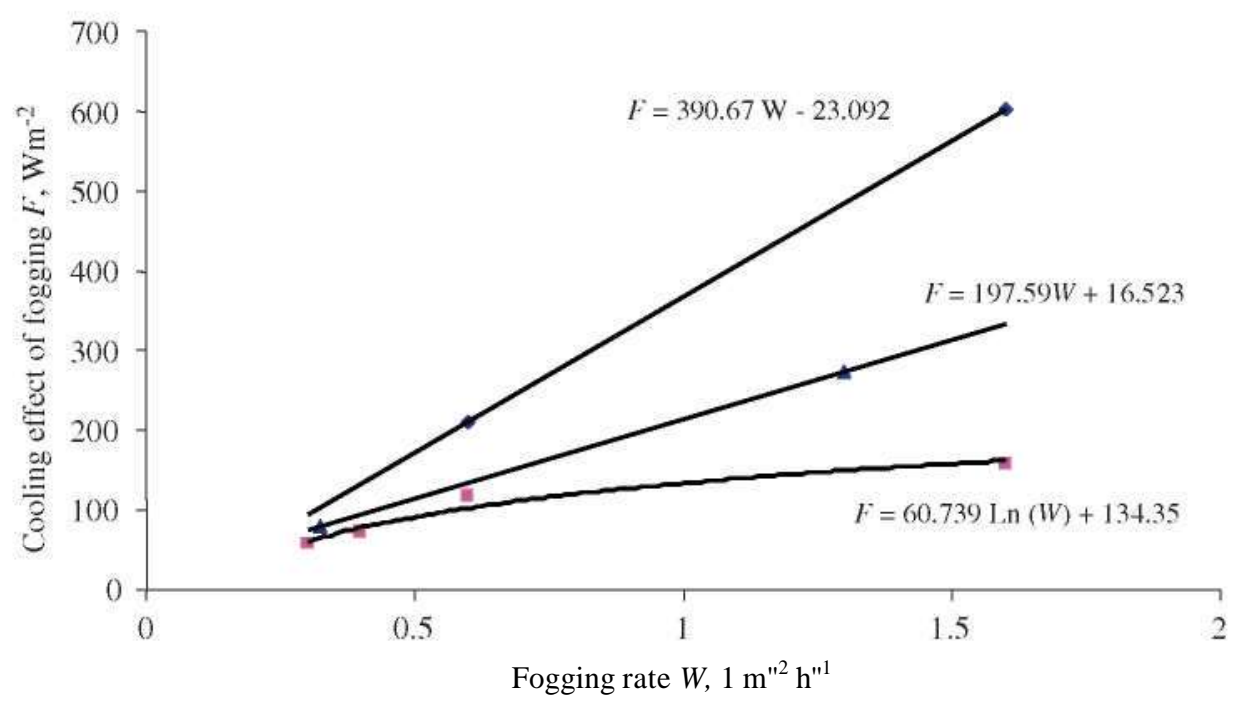

Fig. 4 - Linear and logarithmic regression fit for cooling effect of fogging in $\mathrm{W} \mathbf{m}{ }^{2}$, as a function of the consumed fogging rate in $\operatorname{lm}{ }^{2} h^{-1}$ : •, without a screen; A, with a screen (fogging under); a, with screen (fogging above).

Table 6 - Absolute mean error in the simulation of inside temperature; fitting error for 2002 and validation error for 2003

\begin{tabular}{lcc}
\hline \multirow{2}{*}{ Cooling strategy } & \multicolumn{2}{c}{ Mean temperature error, ${ }^{\circ} \mathrm{C}$} \\
\cline { 2 - 3 } & \multicolumn{2}{c}{ Year } \\
\cline { 2 - 3 } & 2002 & 2003 \\
\hline 1 & 1.49 & 1.30 \\
2 & 1.05 & 1.19 \\
3 & 1.36 & 1.30 \\
4 & 1.02 & 1.05 \\
5 & 0.92 & 1.29 \\
6 & 0.94 & \\
7 & 1.24 & \\
8 & 0.94 & 1.23 \\
9 & 1.30 & \\
\hline
\end{tabular}

assign a constant cooling effect of fogging to each applied water rate.

\subsection{Model validation}

The errors that were obtained by applying the model fitted according to the data of the year 2002 to the data collected during 2003 are summarised in Table 6. The error obtained in fitting and validation was similar and less than $1.5^{\circ} \mathrm{C}$.

Fig. 5 is a graph plotting the inside temperature and temperature simulated by the model throughout one day of validation for cooling strategy 4 (shade screen and belowscreen fogging at a rate of $8 \mathrm{~s}$ cycles every minute). It is observed that the model fits quite accurately. Fogging was done from 13:00 to $18: 00 \mathrm{~h}$.

\subsection{Simulation}

Fig. 4 illustrates the regression fit for cooling effect of fogging $\mathrm{F}$ in $\mathrm{Wm} \sim^{2}$ as a function of the fogging rate $\mathrm{W}$ in $1 \mathrm{~m}^{2} \mathrm{hr}^{1}$ for each of the three cases examined; trials without a shade screen, under-screen fogging and above-screen fogging.

The regression formulae obtained were as follows:

$F=390.67 \mathrm{~W}-23.09$ fogging without a screen

$\mathrm{F}=197.59 \mathrm{~W}+16.52$ fogging under a screen

$\mathrm{F}=60.74 \mathrm{Ln}(\mathrm{W})+134.35$ fogging above a screen

It is clear that the cooling effect is greater with the strategy where no shade screen is used, probably because more radiation penetrates into the greenhouse and therefore more water can be evaporated. Of the strategies that use a shade screen, as already established from the analysis of variance, cooling is greater if fogging is carried out underneath the screen; the difference for each fogging rate can be quantified by regression.

\subsubsection{Reference simulation tuith on/off control}

Table 7 summarises the mean temperature in ${ }^{\circ} \mathrm{C}$, mean maximum temperature in ${ }^{\circ} \mathrm{C}$ and mean water consumption in $1 \mathrm{~m} \sim^{2} \mathrm{day}^{-1}$ data obtained in each simulation for rates of $0.5,1$ and $1.51 \mathrm{~m} \sim{ }^{2} \mathrm{~h}^{-1}$, as well as for the rate in $1 \mathrm{rrr}^{2} \mathrm{~h}^{-1}$ that achieved the same mean maximum temperature in the simulation using the PWM strategy. For example a fogging rate of $1.3561 \mathrm{~m} \sim{ }^{2} \mathrm{~h}^{-1}$ with on-off control and the variable fogging rate with PWM control produced the same mean maximum temperature, $31.35{ }^{\circ} \mathrm{C}$, for the cooling strategy without screen.

The results obtained can be used to estimate the changes that take place with respect to temperatures and water consumption if the rate of fogged water is changed or the shade screen is added. For example, increasing a fogging rate of $0.51 \mathrm{rrr}^{2} \mathrm{~h}^{-1}$ without shading to $11 \mathrm{rrr}^{2} \mathrm{~h}^{-1}$ amounts to a 


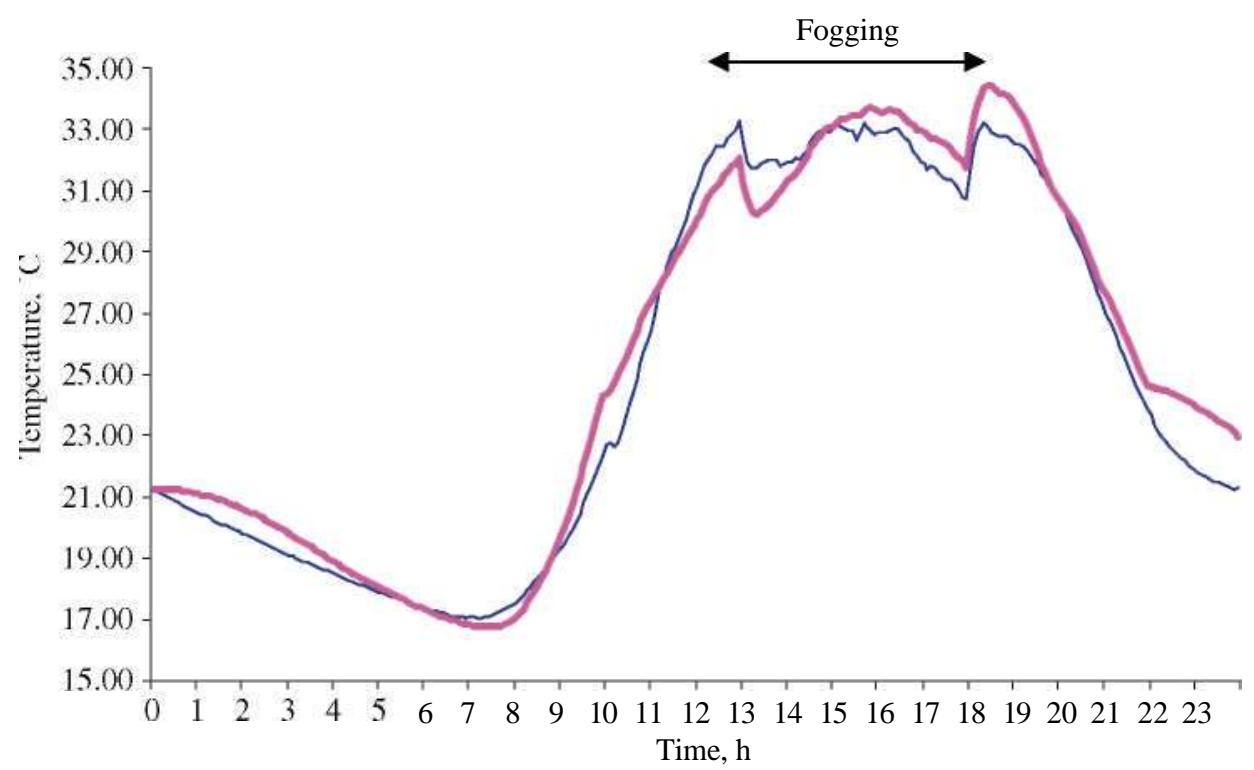

Fig. 5 - Inside temperature (—) and temperature simulated by the model (-) compared throughout an average day in 2003 for the experimental cooling strategy 4 (shade screen, plus below-screen fogging with $8 \mathrm{~s}$ cycles every $1 \mathrm{~min}$ ).

Table 7 - Values simulated by the climate model: cooling effect of fogging $F$ for each water rate, mean temperature, mean maximum temperature and mean consumption for the cooling strategies without screen, with under-screen fogging and with above-screen fogging. Reference on/off control

\begin{tabular}{|c|c|c|c|c|}
\hline $\begin{array}{l}\text { Water flow rate, } \\
\text { lrrr }{ }^{2} !-^{1}\end{array}$ & $\begin{array}{c}\text { Cooling effect of fogging, } \\
\qquad \mathrm{Wm} \sim^{2}\end{array}$ & $\begin{array}{l}\text { Mean temp., } \\
{ }^{\circ} \mathbf{C}\end{array}$ & $\begin{array}{c}\text { Max. mean } \\
\text { temp., }{ }^{\circ} \mathrm{C}\end{array}$ & $\begin{array}{c}\text { Mean water consumption, } \\
\qquad 1 \mathrm{~m}^{2} \mathrm{day}^{-1}\end{array}$ \\
\hline \multicolumn{5}{|l|}{ Without a screen } \\
\hline 0.5 & 172.2 & 24.71 & 33.82 & 4.14 \\
\hline 1 & 367.6 & 24.21 & 32.31 & 7.60 \\
\hline 1.5 & 562.9 & 23.83 & 31.04 & 10.27 \\
\hline 1.356 & 506.7 & 23.93 & 31.35 & 9.61 \\
\hline \multicolumn{5}{|c|}{ With a screen, /ogging under } \\
\hline 0.5 & 115.3 & 23.31 & 30.64 & 2.73 \\
\hline 1 & 214.1 & 23.06 & 29.64 & 4.91 \\
\hline 1.5 & 312.9 & 22.90 & 29.03 & 6.39 \\
\hline 2 & 411.7 & 22.82 & 28.87 & 7.15 \\
\hline \multicolumn{5}{|c|}{ With a screen, /ogging above } \\
\hline 0.5 & 92.2 & 23.37 & 30.91 & 2.79 \\
\hline 1 & 134.3 & 23.26 & 30.43 & 5.35 \\
\hline 1.5 & 159.0 & 23.19 & 30.16 & 7.84 \\
\hline 1.05 & 137.3 & 23.25 & 30.39 & 5.61 \\
\hline
\end{tabular}

$3.51 \mathrm{~m} \sim^{2} \mathrm{day}^{-1}$ increase in water consumption, reducing the mean temperature by $0.5{ }^{\circ} \mathrm{C}$. Adding a shade screen with below-screen fogging at the same fogging rate amounts to a reduction in water consumption of $1.41 \mathrm{~m}^{-2} \mathrm{day}^{-1}$, reducing the mean temperature by $1.4^{\circ} \mathrm{C}$.

\subsubsection{Simulation tuith pulse width modulation control}

To calculate the rate and respective cooling effect of fogging $\mathrm{F}$ in $\mathrm{Wm} \sim^{2}$ to be applied as a function of the error in ${ }^{\circ} \mathrm{C}$ at temperatures above $28^{\circ} \mathrm{C}$, the equations for the two parameters were fitted using the Microsoft Excel ${ }^{\circledR}$ SOLVER, the objective being to minimise the fogging rate applied without increasing the temperature. Rates under $0.51 \mathrm{~m} \sim^{2} \mathrm{~h}^{-1}$ or over $1.51 \mathrm{~m} \sim^{2} \mathrm{~h}^{-1}$ were not used. The linear formulae obtained for both the fogging rate $\mathrm{W}$ in $1 \mathrm{~m} \sim{ }^{2} \mathrm{~h}^{-1}$ and the cooling effect of fogging as a function of error $\left(\mathrm{T}_{\mathrm{sim}}-28\right)$ were as follows:

$\mathrm{W}=\left[195.3+97.6\left(\mathrm{~T}_{\text {sim }}-28\right)\right] / 390.67$ without a screen

$\mathrm{W}=\left[98.7+49.3\left(\mathrm{~T}_{\mathrm{sim}}-28\right)\right] / 197.59$ with a screen (fogging under)

$\operatorname{Ln}(\mathrm{W})=\left[-42.1+16.6\left(\mathrm{~T}_{\mathrm{sim}}-28\right)\right] / 60.74$ with a screen (fogging above)

$\mathrm{F}=172.2+97.6\left(\mathrm{~T}_{\text {sim }}-28\right) \quad$ without a screen 
$\mathrm{F}=115.3+49.3\left(\mathrm{~T}_{\text {sim }}-28\right) \quad$ with a screen (fogging under)

$\mathrm{F}=92.2+16.6\left(\mathrm{~T}_{\text {sim }}-28\right) \quad$ with a screen (fogging above)

Fig. 6 shows the cooling effect of fogging in $\mathrm{WnT}^{2}$ applied as a function of the error with respect to the $28^{\circ} \mathrm{C}$ temperature setting for the three groups of equipment combinations. The cooling effect of fogging can be calculated from the fogging rate using Eqs. (2)-(4), Section 3.4.

Table 8 summarises the mean temperatures, the mean maximum temperatures and mean consumption for each of the equipment combinations with PWM control. The best result was obtained in the case of fogging under the screen with a consumption of $6.11 \mathrm{~lm} \sim^{2} \mathrm{day}^{-1}$, a mean temperature of $22.9^{\circ} \mathrm{C}$ and a mean maximum temperature of $28.9^{\circ} \mathrm{C}$, with respect to a mean outside temperature of $22.8^{\circ} \mathrm{C}$.

It is clear that the water consumption values obtained are lower for all combinations of equipment with PWM control than for the simulation with on/off control for the same mean maximum temperature values. The estimated water saving was $12.3 \%$ without shade, $14.7 \%$ with below-screen fogging and $8.3 \%$ with above-screen fogging.

Fig. 7 represents the inside temperature changes on an average day for the reference simulation (on/off control) and simulation with PWM control from 10:00 to 23:00 h in a greenhouse without a shade screen. The temperature is found to fluctuate more with the reference control, whereas the temperature changes take place more gradually in the simulation with PWM control; this is because the fogging rates are also applied gradually, as shown in Fig. 8. The mean temperature is lower in the reference simulation $\left(23.93{ }^{\circ} \mathrm{C}\right)$ than in the PWM control simulation $\left(24.10^{\circ} \mathrm{C}\right.$; Table 7 , without shade screen). The water saving with PWM control is therefore achieved, by allowing the mean temperature to increase slightly but maintaining the same mean maximum temperature.

Fig. 9 illustrates the temperature as a function of time, simulated for an average day from 10:00 to 23:00 $\mathrm{h}$ for different cooling strategies with PWM control. It is found that the cooling strategy with fogging under the shade screen yields lower temperatures in the greenhouse than those obtained without a shade screen and with fogging above the shade screen.

Comparing the fogging rate as a function of time for an average day from 10:00 to $23: 00 \mathrm{~h}$ for the different cooling strategies with PWM control, it is found that there is a significant difference between consumption with and without a shade screen (Fig. 10). If no shade screen is used, fogging starts much earlier in the morning (11:00h). In strategies with a shade screen, fogging starts in the afternoon, round about $13.30 \mathrm{~h}$.

Finally, Fig. 11 illustrates the different energy fluxes in $\mathrm{Wm} \sim^{2}$ as a function of time for experimental strategy 4 in the year 2003, calculated for an average day from 00:00 to 23:55 h.

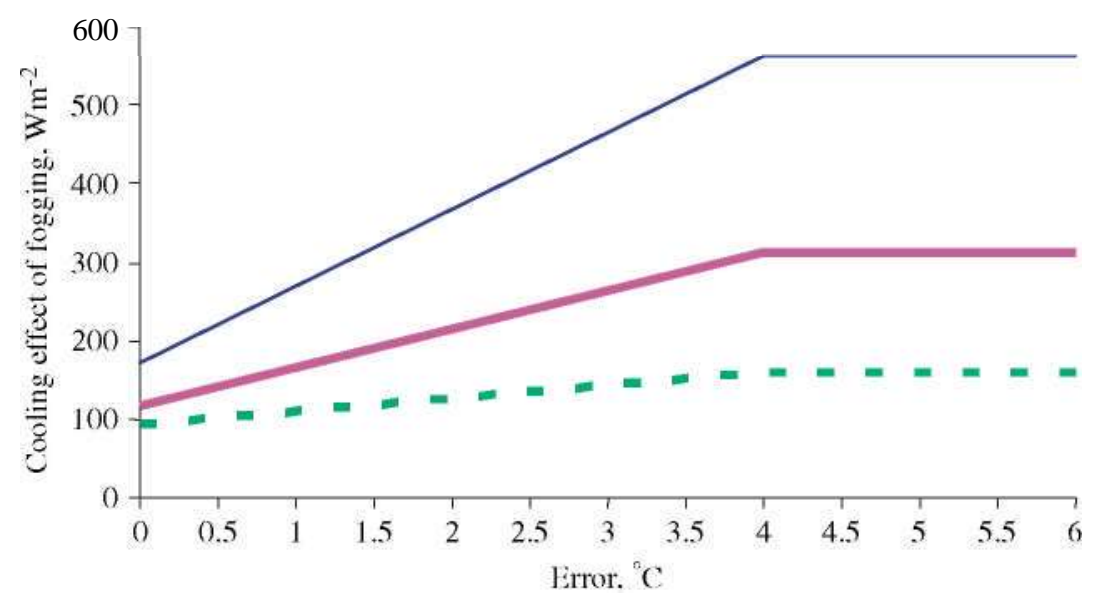

Fig. 6 - Graph comparing the cooling effect of fogging in $\mathrm{W} \mathrm{m}{ }^{2}$, as a function of error in $\mathrm{C}$, for the different cooling strategies with Pulse Width Modulation (PWM) control, without a screen (—), with under-screen fogging ( - ) and with above-screen fogging (—).

Table 8 - Values simulated by the climate model: mean temperature, mean maximum temperature and mean consumption for the cooling strategies without a screen, with under-screen fogging and with above-screen fogging; pulse width modulation (PWM) control

Cooling strategy

Without a screen

With a screen, fogging under

With a screen, fogging above
Mean temp., ${ }^{\circ} \mathrm{C}$

24.10

22.93

23.27
Max. mean temp., ${ }^{\circ} \mathrm{C}$

31.35

28.87

30.39
Mean consumption, $1 \mathrm{~m}^{2}$ day ${ }^{\mathrm{a}}$

8.43

6.10

5.14 


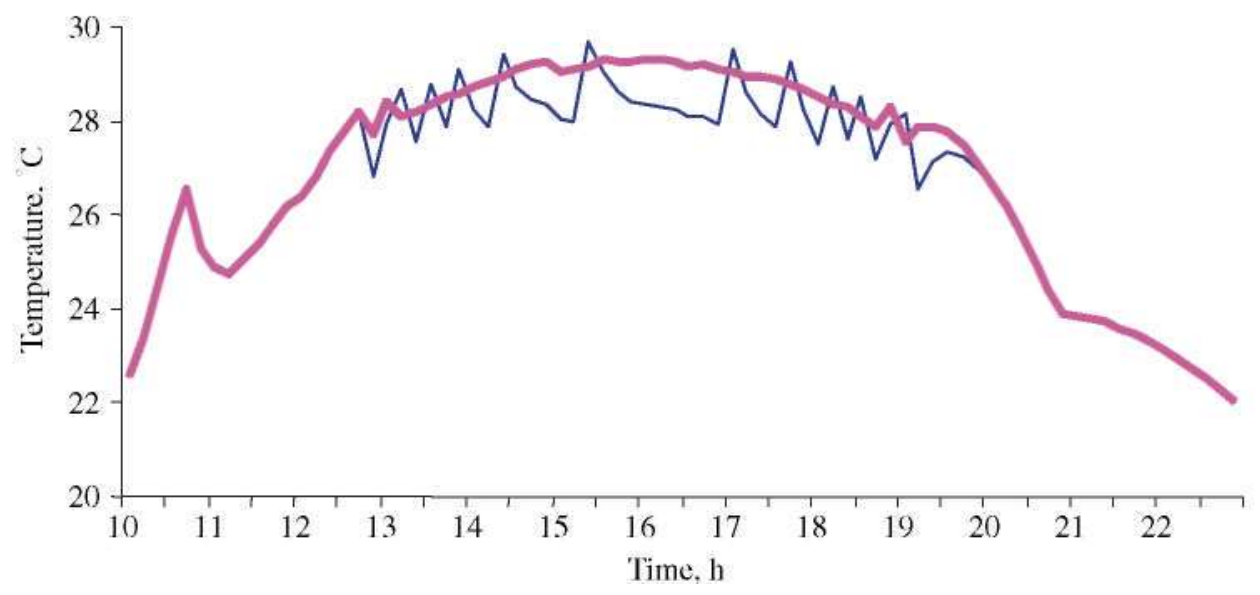

Fig. 7 - Graph comparing the temperature simulated by the model in C, obtained from 10:00 to 23:00 for an average day with the no-screen strategy; temperature for the reference simulation with on/off control ( $—$ ) and temperature for the simulation with pulse width modulation (PWM) control (-).

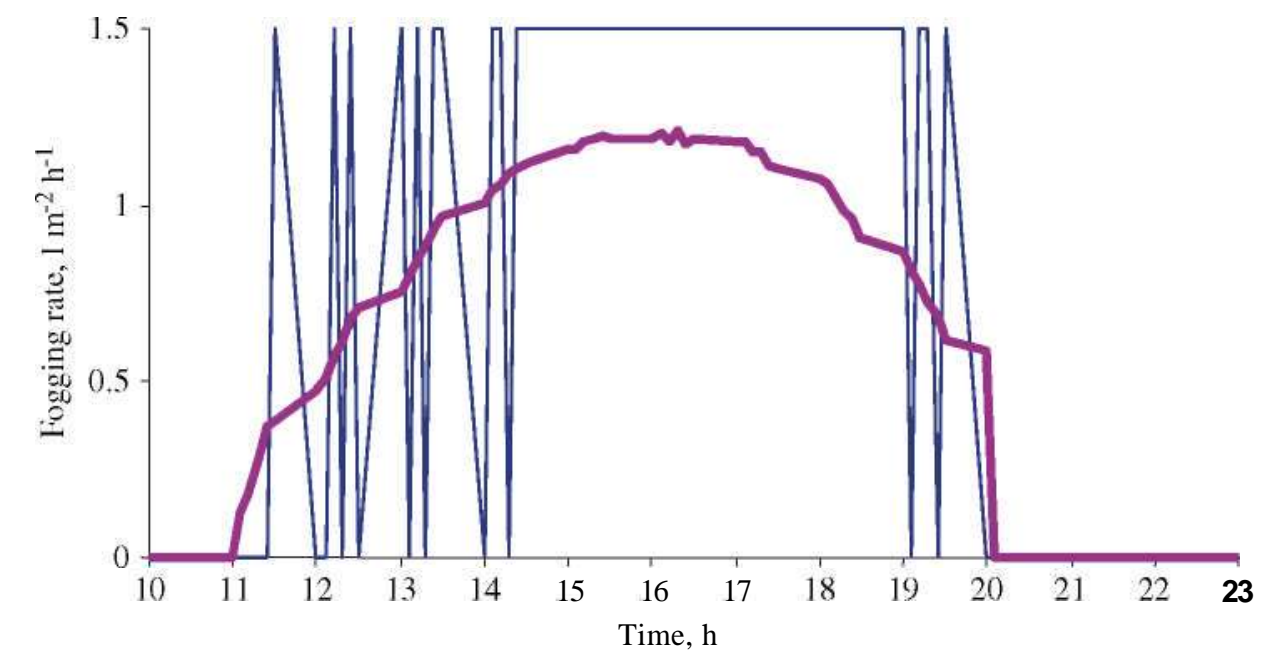

Fig. 8 - Graph comparing fogging rate in $1 \mathrm{~m}^{2} \mathrm{~h}{ }^{\mathrm{a}}$ output by the climate model from 10:00 to 23:00 on an average day for the no-screen strategy; flow for the reference simulation (_ flow for the simulation with pulse width modulation (PWM) control $(\wedge \wedge-)$.

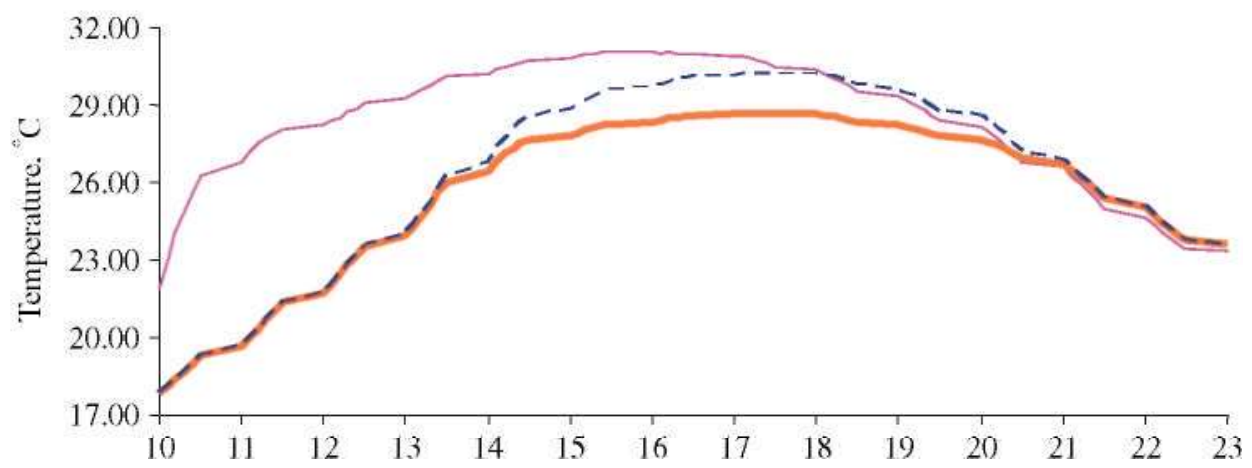




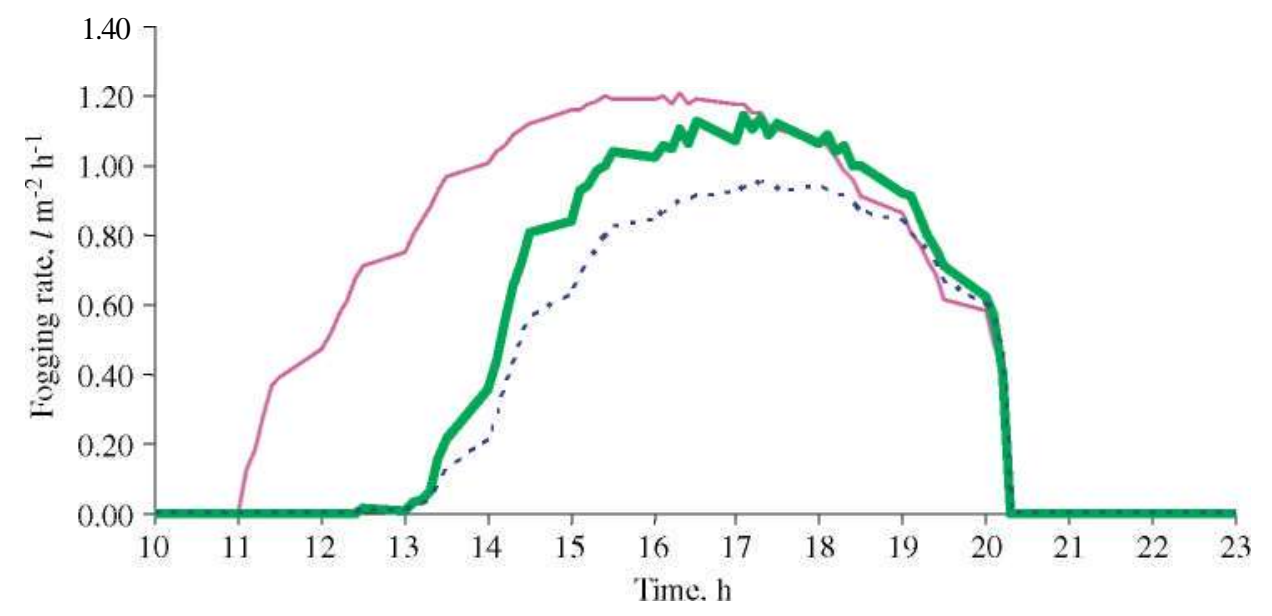

Fig. 10 - Graph comparing fogging rate, $\operatorname{lm}{ }^{2} h{ }^{a}$, as a function of time for an average day from 10:00 to 23:00 for all the cooling strategies with pulse width modulation (PWM) control without a screen (-), with under-screen fogging ( ), with above-screen fogging (—). Mean data are given in Table 8.

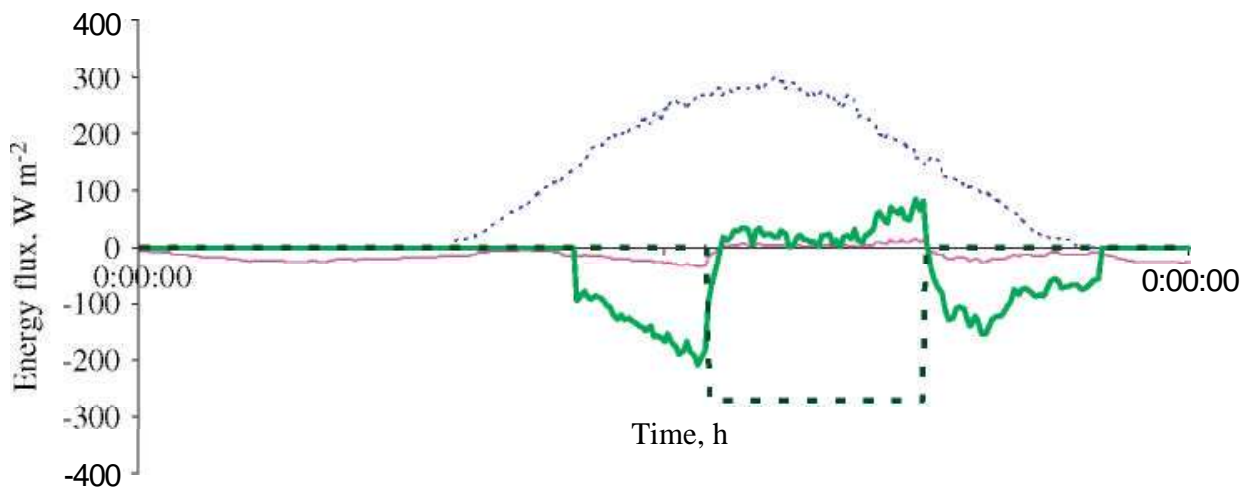

Fig. 11 - Energy fluxes in $\mathrm{Wm}^{2}$, as a function of time for an average day from 00:00 to 23:55 with cooling strategy 4 (year 2003). Flux due to solar radiation (-), losses through cover (-), losses through ventilation (

) and flux due to fogging $(---)$.

It is observed that the model can be used to estimate the energy fluxes in any of the tested situations.

\section{Conclusions}

The combination of ventilation with shade screening and low-pressure fogging above the screen (all of which requires low-cost equipment) yielded inside temperature reductions close to those achieved by fogging under the screen (temperature gap of between +1.0 and $-1.0{ }^{\circ} \mathrm{C}$ ), but did not produce high humidity levels around the plant (mean relative humidity lower than 50\%). It is therefore a suitable combination of equipment for crops that require cooling and relative humidity values far from saturation.

A simple in situ calibration climate model has been used to evaluate the energy fluxes involved. This model can be easily used for control simulations. The absolute mean error for the calculation of the inside temperature was under $1.5^{\circ} \mathrm{C}$.

The control of fogging using the PWM technique, regulating the fogging rate applied as a function of the inside temperature error yielded an estimated water saving of between $8 \%$ and $15 \%$ as compared with on/off control with fixed fogging cycles. PWM is a method of controlling the fog system as a function of cooling needs. The water saving with PWM control is achieved by allowing the mean temperature to increase slightly but maintaining the same mean maximum temperature.

\section{Acknowledgements}

Funding for this research was received from the Spanish Ministry of Science and Technology project AGL2005-06492C03-03 'Evaluation de modelos climdticos como elemento de ayuda a la decision en el diseno de inuernaderos' [Evaluation of climate models as a decision-making aid for greenhouse design].

R E F E R E N C E S

Albright L D; Seginer I; Marsh L S; Oko A (1985). In situ thermal calibration of unventilated greenhouses. Journal of Agricultural Engineering Research, 31(3), 265-281 
Arbel A; Barak M; Shklyar A (2003). Combination of forced ventilation and fogging systems for cooling greenhouses. Biosystems Engineering, 84(1), 45-55, doi:10.1016/ S1537-5110(02)00216-7

Arbel A; Shklyar A; Barak M (2000). Buoyancy-driven ventilation in a greenhouse cooled by a fogging system. Acta Horticulturae, 534, 3327-3334

Arbel A; Yekutieli O; Barak M (1999). Performance of a fog system for cooling greenhouses. Journal of Agricultural Engineering Research, 72, 129-136 (Article No. jaer. 1998.0351)

Boulard T; Bailie A (1993). A simple greenhouse climate control model incorporating effects on ventilation and evaporative cooling. Agricultural and Forest Meteorology, 65, 145-157

Carpenter W J; Willis W W (1957). Comparison of low pressure mist atomised fog and evaporation fan and pad systems for greenhouse cooling and plant response. Journal of American Society for Horticulture Science, 70, 490-500

Giacomelli G A; Ginigers M S; Krass A E; Mears D R (1985). Improved methods of greenhouse evaporative cooling. Acta Horticulturae, 174, 49-55

Hanan J J; Holley W D; Goldsberry K L (1978). Greenhouse Management. Springer-Verlag, New York 530p

Katsoulas N; Bailie A; Kittas C (2001). Effect of misting on transpiration and conductances of a greenhouse rose canopy. Agricultural and Forest Meteorology, 106, 233-247

Kittas C; Katsoulas N; Bailie A (2001). Influence of greenhouse ventilation regime on the microclimate and energy portioning of a rose canopy during summer conditions. Journal of Agricultural Engineering Research, 79(3), 349-360
Kittas C; Bartzanas T; Jaffrin A (2003). Temperature gradients in a partially shaded large greenhouse equipped with evaporative cooling pads. Biosystems Engineering, 85(1), 87-94, doi:10.1016/S1537-5110(03)00018-7

Luchow K; von Zabeltitz C (1992). Investigation of a spray cooling system in a plastic-film greenhouse. Journal of Agricultural Engineering Research, 52(1), 1-10

Montero J I; Anton A; Biel C; Franquet A (1990). Cooling of greenhouse with compressed air fogging nozzles. Acta Horticulturae, 281, 199-209

Oztiirk H H (2003). Evaporative cooling efficiency of a fogging system for greenhouses. Turkish Journal of Agricultural and Forestry, 27, 49-57

Oztiirk H H; Bascetincelik A (2002). Seralarda Havalandirma, Turkiye Ziraat Odalari Birligi Yayinlari, Vol. 227, Ankara

Perales A; Perdigones A; Garcia J L; Montero J I; Anton A (2003). El control de la condensacion en invernaderos. [Condensation control in greenhouses]. Revista Horticultura, 168, 14-19

Perdigones A; Pascual V; Garcia J L; Nolasco J; Pallares D (2005). Interactions of crop and cooling equipment on greenhouse climate. Acta Horticulturae, 691, 203-208

Perdigones A; Garcia J L; Pastor M; Luna L; Benavente R M; Chaya C; De la Plaza S (2006). Effect of heating control strategies on greenhouse energy efficiency: experimental results and modeling. Transactions of the ASABE, 49(1), 143-155

Seginer I (1984). Transpirational cooling of a greenhouse crop with partial ground cover. Agricultural and Forest Meteorology, 71, 265-281 